\title{
REIMAGINING THE FLUID CATEGORIZATION OF THE COMMUNIST, CHINESE, AND JEWS IN UMAR KAYAM'S FICTION
}

\author{
Paulus Sarwoto \\ Universitas Sanata Dharma \\ sar@usd.ac.id
}

\begin{abstract}
This article examines how Umar Kayam's fiction reveals the logic underlying the New Order political legacy through the reproduction of the myth of ethnic purity and anti-communist discourse. It argues that Kayam's fiction, especially "Musim Gugur Kembali di Connecticut" ("Fall in Connecticut," 1967), "Sri Sumarah" (1970), "Bawuk" (1973), Para Priyayi (The Nobles, 1992) and his last novel, Jalan Menikung (The Winding Road, 1999), reflect how that essentialist discourse believing in the primacy of certain ethnic and class categories has been deployed effectively in the Indonesian political arena to create false consciousness among the masses. Kayam challenged this by offering a fictional figuration of fluid identity-identity whose quality is not determined by boundaries of race and class categories of the communist, Chinese and Jewish characters. The texts also signify the narrowing of Homi K. Bhabha's (2002) third space, leaving fewer courses of action for priyayi (Javanese nobles), resulting prominently in corruption. The third space in the Javanese priyayi context does not become a site of empowerment but of corruption and manipulation. It emerges in Kayam's essentialist priyayi characters who believe in the primacy of Javanese priyayi class not as a progressive reconstruction of the site of postcolonial politics, but as a failure to find a moral center for the emergent nation.
\end{abstract}

\section{Keywords}

New Order, Gestapu, Lekra, Marxism, marriage, abangan, race, prejudice

\begin{abstract}
About the Author
Paulus Sarwoto is an Associate Professor and Chair of the Graduate Program in English Language Studies, Universitas Sanata Dharma, Yogyakarta, Indonesia. His PhD is in Comparative Literature and Cultural Studies from Monash University and his MA is in Comparative Literature from Louisiana State University. His research interests include postcolonial theory, cultural studies, and comparative literature.
\end{abstract}




\section{INTRODUCTION}

Comprising more than 300 ethnic groups with a long history of colonization, Indonesia has been a site of endless contestation and manipulation for domination. Contestation among local sultanates in colonial times was manipulated by the colonial machinery for easier control of the colony. Social classes within an ethnic group like the Javanese nobility (priyayi) and peasantry (abangan), were also engineered to make the colonial machinery more effective and efficient at the cost of the lowest class, the peasantry. ${ }^{1}$ In the postwar period, the New Order kept exploiting the diverse ethnic groups and social inequality for political hegemony through the exercise of power. Now in the supposedly more democratic Indonesia, it turns out that the myth of ethnic purity maintained by the colonial and New Order systems has never really gone away. It has even become worse with the present political trend to exploit religious sentiment and anti-communist jargons for vote-gathering in both local and national elections.

Indonesian literature and literary criticism were apolitical, especially since the 1965 anti-communist cleansing. A passing mention of the destruction of Parukvillage because the villagers were accused of being communists, like the one in Ahmad Tohari's Ronggeng Dukuh Paruk (1982), resulted in Tohari being interrogated by the local military commander for days in 1986 (Nugroho). The military accused Tohari of membership in the Communist Party just because he depicted an incident about the destruction of a village during a communist witch hunt. It begs explanation why Kayam's works problematizing incidents around 1965, such as "Musim Gugur Kembali di Connecticut" ("Fall in Connecticut," 1967), "Sri Sumarah" (1970), and "Bawuk" (1973) got published without complication, although at the time of publication Indonesia had already witnessed what Wijaya Herlambang (2014) calls the transformation from cultural violence to physical violence in a communist witch hunt. The transformation of the 1980 os violence marked the return of physical violence by the state against those accused of supporting communism, including several civil servants who were fired due to their association, both real and imagined, with communism. Kayam's position as a professor in a state university and former director general under the Soeharto presidency was perceived to be a part of the New Order structure and this perception might have helped the publication of his works, not to mention his ambivalent writing style in which he criticizes communism while sympathizing with former communist figures. I will elaborate this ambivalence further in the analysis.

As a member of the priyayi class and a part of New Order regime, Kayam's subject position as a fiction writer is unique. Born to a priyayi family, Kayam is able to critically portray what Clifford Geertz refers to as the rigid triadic category

of this class. Through his works "Musim Gugur Kembali di Connecticut" ("Fall 
in Connecticut," 1967), "Sri Sumarah" (1970), "Bawuk" (1973), Para Priyayi (The Nobles) (1992), and his last novel Jalan Menikung (The Winding Road, 1999), he deconstructs Geertz's triadic division of Javanese society of santri, priyayi and abangan into more fluid categories. Class and race boundaries often overlap, not only among the three categories based on social class, but also across race involving the Chinese and the Jews, two race categories often viewed antagonistically. As an insider of the New Order regime, it is the fluidity of communist and non-communist political groupings set up by the state that Kayam negotiates through these stories. These works of fiction show in different ways how the third space-a term I adopted from Homi K. Bhabha to mean the in-between-ness of opposing races and social classes - is a liquid categorization and the priyayi class's failure to grasp its fluidity has turned them into figures without a moral center for an emergent Indonesian nation. In the following analysis, I will explore Kayam's strategy of re-imagining ethnic and class categories for a more plural and egalitarian society through the figuration of his priyayi characters.

\section{JAVANESE PRIYAYI}

Priyayi is the Javanese term for Javanese nobility. Etymologically, the term priyayi may have been derived from two Javanese words: para and yayi, meaning the younger brothers (of the king). ${ }^{2}$ This etymological speculation is in line with Geertz's assertion that priyayi originally refers to "a man who could trace his ancestry back to the great semi-mythical kings of pre-colonial Java" (Geertz 229). The two other dominant social groups in Java are the Moslem santri and the syncretic abangan.

The dominance of this tripartite distinction is driven by Geertz's groundbreaking study of Javanese society in Mojokuto from 1953 to 1954, published in his magnum opus, Religion of Java in 1960, which categorized the Javanese into three typologies: syncretistic abangan, Muslim santri, and priyayi. Geertz bases his grouping on people's occupations and religious value systems. Based on their occupation, abangan, santri and priyayi are understood as Java's peasantry, traders, and gentry, respectively (Geertz 228-229). Mapped onto religious structures, the abangan believe in a combination of animism and certain values derived from Hinduism and Islam; the santri adhere to the orthodoxy and orthopraxy of Islam more rigorously than the abangan; while the priyayi, by contrast, although adopting Hinduism like abangan, do so in a more sophisticated way in terms of its philosophical interpretation of Hindu teachings and praxis (Geertz 234-235).

Three periods of Indonesian history are crucial to understanding the development of the social status of the priyayi in the colonial period and after

Kritika Kultura 35 (2020): 196-212

(C) Ateneo de Manila University

<http://journals.ateneo.edu/ojs/kk/> 
independence as reflected in Kayam's works: namely, the context of colonialism in the nineteenth and early twentieth centuries, marked by the beginning of the processes of modernization in the Dutch East Indies; the struggle for Indonesian independence after the Japanese defeat in 1945; and the effects of 1965, the year of the alleged abortive communist coup of September 3oth, also known as Gestapu and Gestok, leading to the rise to power of Soeharto and his New Order. As this study would like to show, Kayam's figuration of the priyayi class is marked with ambivalence between refuting racial and class superiority and accepting more democratic political and racial configuration. His textual strategy is seen in his characterization of priyayi-hood beyond political and racial category in the priyayi protagonists who engage personally with the demonized communist, Chinese and Jews with compassion.

\section{THE COMMUNIST}

Kayam's complex relationship to the Gestapu events of 1965 is reflected in his Gestapu $^{3}$ stories, including "Musim Gugur Kembali ke Connecticut" ("Fall in Connecticut," 1967), "Bawuk," (1970), "Sri Sumarah," (1973) and Para Priyayi (1992). Except for "Para Priyayi," which had been translated into English by Vladislav Zhukov and subsequently published in 2013, the rest of the stories had been translated by Harry Aveling and came out in the collection titled Sri Sumarah and Other Stories (1976). In this post-independence context, some of the priyayi characters in those narratives are involved in Gestapu events to various degrees and all main characters are accused of being members or former members of the Communist Party. Kayam problematizes the relationship between his characters, Sri Sumarah in "Sri Sumarah", Bawuk in "Bawuk", Tono in "Musim Gugur," and Harimurti in Para Priyayi, with the Communist Party. Notwithstanding their compassion for the suffering masses, because of their association with the demonized Communist Party, they are condemned to suffer social ostracism due to having a family member who is a member of the party, or their past involvement with a communist organ. This paradoxical juxtaposition of the demonized Communist Party on one hand, and compassionate communist characters on the other, is Kayam's strategy to re-imagine the fluidity of the social categories priyayi, abangan, and santri as postulated by Geertz. The fact that the priyayi characters such as Bawuk, Tono, and Harimurti decided to side with the common populace, the abangan, in the struggle for social justice is evidence of Kayam's re-imagination of fluid class categories.

Sri Sumarah and Bawuk are associated with Gestapu not because of their direct

involvement in the Indonesian Communist Party but their familial relationship with

Kritika Kultura 35 (2020): 197-212

(C) Ateneo de Manila University

<http://journals.ateneo.edu/ojs/kk/> 
a communist figure-Tun, Yos, and Hassan, respectively. While Sri's stigmatization as a "communist" is because of her communist daughter, Tun, and son-in-law, Yos, in Bawuk's story, her ostracism is caused by marrying a communist cadre, Hassan, whose social status is below her priyayi class. The failed coup in Jakarta has sent Hassan on the run since the communist cleansing sponsored by the army under General Soeharto is not only conducted in Jakarta but also in other smaller cities in Java and beyond. Bawuk refuses to stay put and decides to go underground in search of her fugitive husband. Kayam describes her decision to marry Hassan and her stubbornness to accompany Hassan in hiding instead of seeking refuge in her extended priyayi family. This decision shows her solidarity for the common people who have been framed by the new regime and her support for their struggle for social justice:

Tapi mas-mas, mbak-mbak, mammie-pappie, itulah dunia pilihanku. Dunia abangan yang bukan priyayi, dunia yang selalu resah dan gelisah, dunia yang penuh ilusi yang memang seringkali bisa indah sekali. (Kayam 121)

But I chose his world, the world of the common people, a restless, anxious world, full of sometimes beautiful illusions. (Kayam, translated by Aveling 81)

Kayam describes both Bawuk and Sri Sumarah as anachronistic figures of traditional priyayi victimized by sudden political shifts in a modern setting in different ways. If Bawuk's anachronism lies in her transgression of priyayi decorum for the sake of social justice, Sri's anachronism evidences her hybrid status as a working class priyayi, even suggesting a kind of downward class mobility in the aftermath of the 1965 coup. In the opening of "Sri Sumarah," the class significance of Javanese names are explicitly discussed by Kayam, highlighting the importance of name as a symbol of priyayi class, one of the defining features of the priyayi, and an issue that is also revisited by Kayam in Para Priyayi. Martokusumo, the name that Sri Sumarah adopts after getting married-since it is customary in Java to address a married woman with the husband's name-is indicative of her priyayi status. The word kusumo added to marto signifies that he is descended from a priyayi family - a family with white-collar occupations in contrast to the common populace that sell their manual labor for wages. Kusumo differentiates him from other Martos, such as Martogrobak or Martoglinding, whose suffixes denote common people's occupations, like someone who pulls a cart for a living (Kayam 6). Kusumo is considered more refined compared to grobag or glinding and suitable only for state officials, including teachers like Martokusumo himself. From this perspective, Sri Sumarah's nickname, Bu Guru Pijit (Mrs. Masseuse Teacher), a name she adopted after the death of her husband, sounds peculiar. Pijit or tukang pijit, masseuse, is a non-priyayi occupation whereas guru, teacher, is a priyayi one. This nickname signifies her newly acquired hybrid and ambivalent position

Kritika Kultura 35 (2020): 198-212 
as a result of her transformation. Her position now is located between the priyayi and the working class as a result of the sudden political changes that transpired in 1965. She has been contaminated with Communism by association, making her a dangerous person.

By the end of the story, Sri has become a member of the exploited working class despite her priyayi status. While still priyayi, she is called Martokusumo because her late husband, who went by that name, was a priyayi. When she becomes a professional masseuse, her nickname is Bu Guru Pijit. Sri, a traditional priyayi, is victimized by modern developments yet somehow, the very priyayi values that have contributed to her downfall have also enabled her to survive in the changing situation. In a modern state, being a priyayi without economic power and political position, like Sri, means being condemned to the life of a pariah. Her priyayi identity is no as longer clear-cut as it was when the story began.

In The Location of Culture (1994), Bhabha talks about hybridity as being in two places at the same time or being influenced by both colonizer and colonized but not fully belonging to one of them, within the context of colonial assimilation. But in "Sri Sumarah," hybrid identity is in the context of the complex Javanese transition from the post-independent state to the modern independent state where traditional values are challenged by modernity. Sri's consciousness is that of an elite priyayi but the material reality of her life situates her among the common populace that has been subalternized by the government and society, due to her alleged association with the Communist Party. This degradation of her status to that of the common populace blurs the borders between the wong cilik (common people) and the priyayi that had defined the distinctions for the choices she made in her life. She becomes at once both and none of them. Her association with the Communist Party, no matter how tenuous, in fact, has trapped her in a status which is even below that of the common populace. She is a true subaltern as Gayatri Spivak defines it: a sexed subaltern who has no space from which she can speak (Spivak 307). Not only does Sri have no space to speak from, she is also silenced by the larger narrative of the New Order state and by the remaining priyayi feudal expectations that believe that the powerful can do no wrong. She loses her house, land, community, and her very right to reclaim her identity as a full citizen of Javanese priyayi descent in modern Indonesia. She becomes, in a notorious Indonesian term, "orang tidak bersih lingkungan"-a contaminated person because of one's relation with a communist. This contamination is passed on to her succeeding generations, a political strategy of the regime leading to what Ariel Heryanto calls "the implosion of stigma." A person with such a label will have no access to economic resources, political rights, and government employment. 
This kind of economic, social, and political blacklisting imposed by the new regime befalls the other characters as well. Harimurti in Para Priyayi is fired from his office because of his past involvement in the Communist Party's cultural organ, LEKRA. Although Harimurti's activities in LEKRA are motivated by compassion for the peasants and ideas for social justice, his membership in this communist cultural organ has positioned him as the enemy of the state right after the events of 1965. Tono in "Musim Gugur" faces a similar end. His past membership in the Communist Scholars' organization and LEKRA is also driven by the desire to create a just state, one that does not marginalize the poor and the peasants. Yet even after leaving both organizations, he is still considered dangerous and this leads to his arrest by the army.

Kayam portrays Bawuk, Tono, Harimurti, and Sri Sumarah in ways which signify the priyayi class's failure to redefine itself in the face of this authoritarian regime. The priyayi figures that transgress class boundaries have found themselves obsolete in the post-independence state. Kayam depicts them to be anachronistic in the new regime despite their high moral standards. The characters' efforts to redefine priyayi-hood by crossing the borders between the priyayi and the oppressed peasant have been manipulated by both the Communist Party and the New Order. Since their humanitarian motives are channeled and co-opted by both parties, they become involuntary supporters of political agendas. When they finally try to clarify their involvement with the Communist Party, their voices become subalternized and hence unheard or misunderstood. The state apparatuses will not accept their arguments that they are not involved in Gestapu movements in Jakarta and consequently, they treat them as traitors of the state.

In Para Priyayi, Kayam refers to the essence of prirayi-hood as service for the "little people," the goal of characters like Harimuriu, Bawuk, and Tono. However priyayi-hood also has other dimensions: authoritarianism and discrimination. It is actually adopted by the state in its draconian rule and turned against the more caring aspects of priyayi-hood as represented by the compassionate Bawuk, Tono, Harimurti, and Sri Sumarah. The victory of authoritarianism and discrimination against alleged communists signify the failure of the third space to be a transforming site. The third space as a site of negotiation among the residue of colonialism, traditionalism and emerging nationalism is unable to produce a new state system based on justice and equality. The official history of the communist coup written by the New Order regime provides no space for an alternative story without it being labelled treason against the state. Their figurations as compassionate characters sympathizing with proletarian causes therefore has to meet tragic ends. Such marginalization through ostracism of an ex-communist and his descendants is contrasted with the compassionate characters of the victims. This certainly raises 
a question: How did these Gestapu stories pass the censorship of the New Order regime that framed communists as traitors of the state?

Kayam's sympathy for the Gestapu victims in his stories and the fact that the stories got published without censorship during the heyday of the New Order might be explained in several ways. On the formal level, in contrasting these compassionate figures and the demonized Communist Party, the narratives do not seem to challenge possible fabrication of the Gestapu official narrative and explores the multifaceted Marxist ideology. It means that Kayam sympathizes with the victims but not with the Communist Party and Marxism. In depicting and sympathizing with the victims (Sri, Bawuk, Tono, and Harimurti), Kayam seems to argue that they have been manipulated by the Communist Party instead of the New Regime. In other words, the stories accept the view that the Communist Party corrupts the people and that what happens after 1965 is the price they have to pay for choosing the malignant party. It is only within these boundaries (i.e., the disproportionate sin and punishment on behalf of the tender-hearted victims manipulated by the Communist Party) that Kayam negotiates his disagreement against the state through his writing. As for the unrepentant communist characters such as Hassan and Yos, Kayam appears to agree that they deserve punishment for their ideological beliefs. Kayam's particular sympathy for the repentant victims and his uncritical acceptance of the belief that communism and Marxism were evil might have allowed the New Order regime to tolerate his works.

The other possible reason why the regime took Kayam's stories lightly was because of his support for the New Order from its inception. Upon his return from the United States, he was appointed as the Director General of Radio, Television and Film, staying in the position from 1966 though 1969. Until his death in Jakarta on 16th March 2002, he was active as director of many significant offices such as the Jakarta Art Council (1969-1972), the Centre of Social Sciences Training in Universitas Hasanuddin, and Universitas Gadjah Mada (in 1975-1976 and 19771997, respectively). Pursuing his lifelong career as a civil servant under the regime must have earned the regime's strong confidence in Kayam's support, despite his compassionate depiction of the 1965 victims.

\section{THE CHINESE AND THE JEWS}

In Jalan Menikung, Kayam generalises priyayi values by including Chinese and Jewish American figures as major characters in his narrative. They are two social groups that have often experienced racism in part because of their successful business enterprises whilst being racial minorities in countries in which they are

Kritika Kultura 35 (2020): 201-212

(C) Ateneo de Manila University

<http://journals.ateneo.edu/ojs/kk/> 
seen as outsiders (Chirot and Reid 6). In Indonesia, discrimination against the Chinese has been ongoing since the colonial times, which is part of a larger and more complex set of arguments about racial purity. ${ }^{4}$ Generally speaking, racial purity is a common discourse by racial groups who believe that their racial identity possesses distinctive and higher quality features that segregate them from those possessed by other racial groups. And it is a common discourse adopted by colonizing countries in order to sustain their colonial policy. A colonial discourse in which purity is signified by skin color sees whiteness as the sign that needs to be maintained. In colonial East Indies, the social pyramid structure was arranged with White at the top, the Chinese and Arabs in the middle, and the Javanese at the bottom. After independence, the discourse of racial purity has been reclaimed by the Javanese, positioning them as the most rightful citizens of the Republic, while relegating the Chinese as the second-class citizens. The power structure has changed but the fate of the Chinese remains as a manipulable exclusive minority (Rakindo 126).

The position of the Indonesian Chinese during the New Order was problematical. On the one hand, they benefited financially from cronyism and a corrupt system; on the other, they were stripped of their sociocultural legacy, a situation that might be called "ghettoization of citizen-Chinese-political exclusion and economic privilege" (Anderson 491). Consequently, the very rich Chinese near the power center were capable of influencing national economic policy while the less rich at the periphery had to cope with demands of corrupt officials in order to improve their lot. Further, they were not allowed to retain their Chinese language and names but encouraged instead to adopt Indonesian names. They were recognized as Indonesian citizens (Warga Negara Indonesia-WNI); however, the recognition came with another qualifier, keturunan. WNI keturunan means Indonesian citizen but non-native. The difficult political position of the Indonesian Chinese is explored by Kayam in his last novel, Jalan Menikung.

An interracial marriage in Kayam's Jalan Menikung takes place in the fourth generation of Sastrodarsono's family, with Anna marrying a Chinese Indonesian and Eko marrying a Jewish American. Their marriage is met with mixed feelings and even some degree of antagonism by their priyayi parents. Tommi's antagonism against her daughter, Anna, marrying a Chinese is similar to Noegroho's antagonism against his daughter, Marie, marrying a peasant's son. Through this interracial and inter-social class marriage that parallel these priyayi descendants-namely Eko, Anna, and Marie-Kayam deconstructs stereotypical categorizations of race and class. The younger generation of priyayi is depicted as marrying into social groups often regarded as subaltern classes, the Indonesian Chinese, and enemy of the Islamists, the Jewish. 
As opposed to Kayam's re-imagination of racial equality, the subalternity of the Indonesian Chinese is demonstrated by their being marginalized from government positions and other discriminatory measures, especially during the New Order. ${ }^{5}$ Several incidents involving racial riots in the 1970s, 1980 os and 1990 s indicate that social dissatisfaction against the government was often deflected towards the Chinese Indonesians. ${ }^{6}$ They were often used as targets of racial antagonism to divert people's anger and disappointment about the lack of social and economic progress away from the government. They were also barred from pursuing careers as civil servants and from serving in the military. During the Jakarta pogrom in May 1998, many Chinese Indonesians had to flee abroad. ${ }^{7}$ In the novel, this discriminatory treatment is identified by Harimurti:

Di atas kertas mereka sama haknya dengan kami, apa yang disebut pribumi. Tapi, dalam praktek, hak mereka tidak sepenuhnya dilindungi ...

Mereka ini, keturunan Cina kita ini, mungkin nasibnya masih seperti Yahudi jaman dahulu. Di mana-mana diburu-buru, dipojokkan, diperas, dikurangi hakyna (Kayam 144).

Theoretically they [the Chinese] have the same rights as us, indigenous. But in reality their rights are not protected...

These Chinese Indonesians' fate is similar to the Jews in the past. They are everywhere hunted, cornered, blackmailed and their rights are violated. (Kayam, translated by Zhukov)

Discrimination toward the Chinese is also depicted in Tommi's character. He expresses his strong opposition to Anna, his daughter, marrying a Chinese boy:

Kalian tahu, saudara-saudaraku, nama Handoyo itu sebenarnya? Han Swie Kun! Coba, adik-adikku, darah Sastrodarsono mau dicampur dengan darah Han Swie Kun. Apa tidak kacau nanti! (Kayam 78)

Ini soal darah cucu-cucu saya nanti, Hari. Saya tidak mau kalau darah priyayi Sastrodarsono, ditambah darah pejuang angkatan ' 45 Nugroho, lantas tercampur dengan darah Cina. (Kayam 83)

Do you know what Handoyo's real name is? Han Swie Kun! Imagine brothers, Sastrodarsono's blood will mix with Han Swie Kun's. What a mess! (Kayam, translated by Zhukov)

This is about my grandchildren's blood, Hari. I don't want Sastrodarsono's priyayi blood and Nugroho's warrior blood gets mixed with the Chinese blood. (Kayam, translated by Zhukov) 
Despite Tommi's leaving behind the ideals of priyayi-hood, he still holds the dominant view on the purity of a priyayi biological identity by challenging his daughter's decision to marry a Chinese Indonesian. Kayam's criticism of this racist attitude is of course clearly depicted in his characterization of the Chinese character as embodying true priyayi values.

While the Chinese are relegated to second-class citizenship in post-independent Indonesia, the Jewish figures in Kayam's last novel, Jalan Menikung, are seen with enmity by the Priyayi characters whose religious affiliation is more to Islamic identity. Paradoxically, Kayam configures the Jewish characters without racist sentiment. Generally, postcolonial literature highlights the consequences of the unequal social positioning of people who are identified as belonging to different races, especially in an interracial marriage, because the experience of colonialism highlights the perceived markers of difference. When Eko in Jalan Menikung is hosted by the Levins, a Jewish American family, during his studies in the US, there is no indication of such a colonial or postcolonial component in his reception. Although Claire, their only daughter, also stays at the same house, they do not hesitate to host Eko. Claire seems to enjoy Eko's company and even falls in love with him. When Eko and Claire express their intention to get married, Claire's parents also accept this without reservations.

A very different reaction is seen from the Javanese family's side. Upon receiving a telegram informing them of their son's wedding plans, they and especially his mother, Sulistianingsih, feel offended:

Anak ini sudah luntur, hilang tata karma Indonesianya. Sudah jadi orang Amerika apa? Kalau orang-orang tua kita itu masih ada, oooh akan bagaimana mereka! Melihat cucunya kawin dengan orang asing, Yahudi lagi! (Kayam 38)

This kid has lost his Indonesian politeness. Has he become an American? I couldn't imagine how our ancestors would have reacted: their grandchild is marrying a foreigner, a Jew! (Kayam, translated by Zhukov)

Firstly, the fact that Eko does not consult his family when deciding upon his future wife is considered impolite. Secondly, the fact that Claire is Jewish complicates this marriage. As we notice in Kayam's other stories, typically a priyayi's purity is maintained by marriage between two priyayi descendants and is usually arranged. This is the case for Sastrodarsono and his children, whose marriage was arranged by their parents. With this interracial marriage, Kayam explicitly engages with the supposedly traditional enmity between Islamists and Jews in the context of Java and Indonesia's growing involvement in world politics. Perhaps it is because 
Harimusti's family has adopted a stronger Islamic political identity that this enmity leaves its traces in his mother's worries:

"Eko mau disuruh jadi Yahudi? No way! Tak usah, ya! Paling-paling yang cocok dengan mereka, kita sama-sama mengharamkan daging babi. Tapi masuk agama Yahudi?" (Kayam 39)

“They want Eko to be a Jew? No way! Out of the question! Our only common ground is that both religions forbid us to eat pork. But becoming a Jew?" (Kayam, translated by Zhukov)

Kayam situates this antagonism in a Javanese postcolonial context. In this context, the West is seen not as a single entity such as White European, but includes the American Jews that Eko's mother detests. If in colonial times the Javanese alignment with the Dutch was considered favourable, in post-independence times Eko's alignment with the Jewish family is seen as a big problem by this priyayi family. Their stronger Islamic identity as priyayi Islam rather than priyayi abangan (which would be more syncretistic and tolerant) has made them oppose Jewish identity vehemently.

Kayam offers a different perspective amid this enmity. His works seem to suggest that despite the ubiquitous racial and religious sentiments among the Muslims, there are some common ground on which his characters negotiate their comfort zones. In this case, Kayam extends priyayi values by going beyond class and race. An American immigrant writer, such as Tahira Naqvi, has explored the similarity between Muslims and Jews in his short story, "Thank God for the Jews." Kayam, who might have read the story, also describes the common ground that the two faiths share. Kosher for the Jews and halal for the Muslims refer to dietary laws in accordance with their scriptures. The characters in Naqvi's story thank the Jews because they believe that kosher meat in Jewish stores is halal due to similar slaughter methods prescribed by Islamic scripture. Kayam also explores the similarities between Islam and Judaism in this last novel:

"Kau itu, Alan, sering membingungkan saya. Seakan pastrami kosher atau tidak kosher itu jadi persoalan penting betul buat kamu."

"Iya, dong. Saya kan orang Yahudi. Sebentar lagi kau juga jadi menantu orang Yahudi. Penting dong kosher itu. Seperti agama Islam, kan? Halal!" (Kayam 64)

"Alan, you have often puzzled me. You act as if whether or not the pastrami were kosher an important issue for you."

"Of course, it is important. I am Jewish. You will soon marry a Jewish girl. Kosher is definitely important. Just like in Islam: Halal!” (Kayam, translated by Zhukov)

Kritika Kultura 35 (2020): 205-212 
Kayam also portrays another shared belief between the Jews and Muslims: circumcision as an important religious observance as reflected in the dialogue between Eko and Claire:

"Kenapa pada hari perkawinan kita, kita bicara soal sunat?"

"Entahlah. Mungkin karena saya semakin mantap Islam dan Yahudi banyak persamaannya."

"Karena agama-agama kita sama-sama mengharuskan laki-laki sunat dan sama-sama mengharamkan daging babi dan memotong leher ayam harus sampai mengucurkan darah dan menodainya?" (Kayam 75)

"Why do you talk about circumcision in our wedding day?"

"I don't know. Perhaps because I am getting more convinced that Islam and Judaism have a lot in common."

"Because our religions require men to be circumcised and forbid eating pork and stipulate that when slaughtering chickens we have to shed their blood?" (Kayam, translated by Zhukov)

As the novel progresses, Kayam constructs a typically Javanese mystical thought, namely that underneath religious differences there is a similar principle (i.e., the need to be aware of the differences between good and evil). By disregarding outer religious and racial differences, Eko's marriage with a Jewish American challenges his ancestors' ideas of racial and religious purity. An Islamic identification that is still a strong part of the family up to the third generation represented by Kayam is reinterpreted in a characteristically Javanese mystical way by the fourth generation. Javanese mysticism is more adaptive to new influences than many other religious formations and this helps Eko to become a cultural commuter. Eko welcomes a different religion as part of himself represented by his Jewish wife without qualms since he feels comfortable relating with Jewish values while still embracing his version of Islam. Ashcroft (207) notes that "the paradox of global culture is that it makes itself 'at home' in motion rather than in place." Eko as a global citizen does not have to rely on his origin-geographical, cultural, nor even religious-to feel at home. In fact, his geographical home has refused him due to his father's involvement in the banned Communist Party. His exilic life and his interracial marriage have taught him to be at home in motion, unlike his priyayi relatives who prefer to settle in Java to make that their home.

Eko is also depicted by Kayam as a priyayi figure who sees the familial bond in different way-the kind of bond in which individualism is more prominent than collectivism. He is adopting the American concept of being a responsible adult to whom individualism is more valued than the familial bond: 
Kemudian, kalau sudah tamat, apalagi sudah mencapai umur dewasa, mereka harus bertanggung jawab keapada dirinya sendiri. Anak itu sudah harus mandiri. Dia juga sudah menjadi "merdeka”. Dan Orang tua, apalagi keluarga besar, tidak akan menuntut janji apa-apa dari anak-anaknya. Hidup dijalani sendiri. (Kayam 22)

After graduation, especially if he is an adult, he has to be responsible for his own life. He has to be independent. He also becomes "free." And his parents, moreover his extended family, will not ask for anything from their child. Life has to be lived alone. (Kayam, translated by Zhukov)

This is clearly seen in his marriage procedure that does not comply with traditional priyayi standards. He marries a Jewish American in a civil ceremony without seeking the advice of his extended family, in contrast to the traditional practice upheld by the Sastrodarsono's extended family. Kayam portrays Harimurti's family as the first to set Eko free from familial and class bond. Indeed, in the novel, Kayam seems to argue that collectivism that emphasises harmony and kinship in the Javanese culture has become potentially corrupting when set against an international background. The figuration of wealthy but corrupt priyayi, like Tomi, thriving in the young republic is contrasted with Eko who is ostracized by his state merely because of his father's past involvement with the cultural organ of the Communist Party.

In a discussion hosted by the Kompas Daily in 1986, Kayam points out two important traditional values potentially corrupting Indonesian minds, namely keharmonisan (harmony) and kekeluargaan (kinship, "cronyism") ${ }^{8}$ These aspects of Javanese wisdom were not evil in themselves but when wrongly enacted, can been shown to be a fertile source of economic and political corruption. In the same forum, Kayam also critically reassessed some Javanese ascetic practices, such as sleeping on the floor and fasting, and concluded that such practices were often motivated by desire for material wealth: to be rich, therefore able to live in luxury. In this context, the ascetic practices are considered an opportunistic laku, practice, to gain a strong financial, social, or political position for himself or his descendants. As such, Kayam calls this uncritical reverence for the traditional values of one's own culture damaging to the nation, "kompleks narsisme budaya" (cultural narcissism complex) (dn/efix).

In the novel, this unthinking reverence for traditional values has led the Javanese to blame the Chinese for the economic inequality that the postcolonial state has created: 
Salah mereka karena mereka bekerja keras lebih dari bangsaku dan sering jauh lebih berhasil, yang menerbitkan rasa cemburu bangsaku yang lebih malas, mau enak-enak saja, mau memetik hasil kerja keras keturunan Cina itu. (Kayam 114-115)

It was their [the Indonesian Chinese] own fault because they worked harder and were much more successful than my people. This incited jealousy. My people were lazier, never worked hard and just wanted to reap what the Chinese had struggled for. (Kayam, translated by Zhukov)

This autocriticism that Kayam expresses through Jalan Menikung makes it clear that priyayi racial prejudice against the subaltern classes is unfounded, since the Chinese work harder than the priyayi. Against the stereotypical image of stingy Chinese Indonesians, Kayam presents the reverse. Anna's Chinese husband, Boy, for instance, is described as "pintar, cerdas, tidak sok, baik hati, rendah hati, simpatik" (clever, smart, not vain, kind, humble, and sympathetic) (79). Contrary to the antiSemitic sentiment, Kayam presents the Levins as compassionate and kind. They do not view their daughter's relations with a Javanese boy with any racial prejudice.

By putting forward compassionate Jewish characters Kayam posits that the quality of priyayi-hood is not and should not be determined by racial, religious or class identity, but by inner qualities of restraint and selfless service for the people. The novel argues that the quality of priyayi-hood is not only found in the Javanese priyayi but is also found in other races, such as Boy, the kind-hearted Chinese, and the Levins, the compassionate Jews. Consequently, individual qualities are more important than collective class and racial identity.

\section{CONCLUSION}

The absurdity of rigid racial and class categories is enacted in Kayam's Gestapu fiction, especially Jalan Menikung. Faced with an authoritarian and corrupt state system, the only options that appear to be left to Kayam's ethnocentric characters are to join the corrupt system and thrive, or refuse the system and perish. These works of fiction show in different ways how the "third space" envisaged by Bhabha (2002) emerges in Indonesia not as a progressive reconstruction of the site of postcolonial politics, but as a failure to find a moral center for the emergent nation. The essentialist priyayi figures manipulate the third space as a site for corrupt attitudes, providing them with material prosperity all while refusing the fluidity of class and racial categories. In contrast, the compassionate priyayi characters do not have a room to raise their concerns and have to be ostracized for their postmodern outlook, viewing racial and class categories as fluid. 
The fluidity of priyayi-hood in Jalan Menikung goes beyond racial and national borders. The novel reveals that the Javanese and the state have failed to revitalize priyayi values to empower the postcolonial state, marked by their failure to reinterpret priyayi-hood in a supposedly democratic system. Refuting the chauvinistic discourse of the Javanese priyayi, the novel presents a wider view that the values initially seen as particularly Javanese are also found in the so-called subaltern groups. The Jewish and the Indonesian Chinese figures are presented as embodying priyayi values that the Javanese characters fail to uphold. The characters of Alan Barnstein, Claire, and the Levins portray the friendly and welcoming side of the American peoples. The stereotype of selfish and money-oriented Indonesian Chinese is deconstructed in the figuration of Boy.

Jalan Menikung apparently presents Kayam's reconstruction of the universality of ideal priyayi values with a special emphasis on the subaltern groups and individualism. This is apparent, for instance, when Kayam names the newborn Jewish-Javanese baby (Eko and Claire's son) Solomon, who, in Kayam's reckoning, is a universal character found in Torah, Bible, and Quran. As such, the identity of the traditional priyayi is no longer important because global interaction has dissolved racial borders, creating another space for the younger generations to inhabit. This liquid identity is represented by Kayam as a peaceful site of existence, though in reality it is still rife with unequal power relations respective to race, gender, and class. Relevant research on the re-imagination of race and class categories in contemporary Indonesian context from other texts is much needed, especially with the current trend of Indonesian politicians deploying populist and divisive rhetoric for political bargaining power. 


\section{Notes}

1. Heather Sutherland elaborates this mechanism in Pangreh Pradja: Java's Indigenous Administrative Corps and Its Role in the Last Decades of Dutch Colonial Rule (1973).

2. See Kartodirdjo, Sudewo, and Hatmosuprobo (1987, p. 3) and Sutherland (1975, p. 57).

3. Gestapu refers to the failed coup d'état staged by a group who called themselves Gerakan Tigapuluh September (the 3oth September Movements, referring to the date of their action), allegedly masterminded by the Communist Party. Broadcasting an official statement the next morning at 7.20 a.m. through the Indonesia national radio broadcaster, RRI, the group announced that they had arrested a number of generals who had been planning themselves to carry out a coup on October 5 th under the code name of Dewan Jenderal (the Generals Council). It turned out that by the time of the broadcast they had killed six top army generals and one adjutant. The army under General Soeharto soon suppressed the coup and had the leaders of the Gestapu jailed or killed.

4. See for instance John T. Sidel (2007) pp. 20-24.

5. For a comprehensive analysis of the discrimination against the Chinese Indonesian during the New Order era, see Charles A. Coppel's Studying Ethnic Chinese in Indonesia (2002), especially chapter 1 . Analysis of this issue can also be seen in articles by Frans H. Winarta (2004), "Racial Discrimination in the Indonesian Legal System: Ethnic Chinese and Nation-Building" and A. Dahana (2004), "Pri and Non-Pri Relations in the Reform Era: A Pribumi's Perspective."

6. See for example the article by Ingrid Wessel (2001), "The Politics of Violence in New Order Indonesia in the Last Decade of the 2oth Century."

7. John T. Sidel (2007, pp. 1-2) mentions that "In May of that year, simultaneous rioting in Jakarta and such cities as Solo, Medan, and Palembang led to the destruction of hundreds of Chinese business establishments, the rape of dozens of Chinese women, and the deaths of more than one thousand people in Jakarta alone."

8. Reported in Kompas (Kristanto and Krastawan, 1986): "Harmoni Sumber Kemandulan" (Harmony as the root of the problem). 


\section{Works Cited}

Anderson, Benedict R. O'G. “Old State, New Society: Indonesia's New Order in Comparative Historical Perspective." Journal of Asian Studies, vol. 42, no. 3, May 1983, pp. 477-496.

Ashcroft, Bill. Post-Colonial Transformation. Routledge, 2001.

Bhabha, Homi. K. The Location of Culture. Routledge, 2002.

Coppel, Charles A. Studying Ethnic Chinese in Indonesia. Singapore Society of Asian Studies, 2002.

Dahana, A. "Pri and Non-Pri Relations in the Reform Era: A Pribumi's Perspective." Ethnic Relations and Nation-Building in Southeast Asia, edited by L. Suryadinata, ISEAS, 2004, pp. 45-65.

dn/efix. "5o Tahun Polemik Kebudayaan: Makin Rumit, Makin Mendesak." Kompas, 1986. Geertz, Clifford. Religion of Java. Free Press, 1964.

Herlambang, W. Kekerasan Budaya Pasca 1965: Bagaimana Orde Baru Melegitimasi AntiKomunisme Melalui Seni dan Sastra. Marjin Kiri, 2013.

Heryanto, Ariel. State Terrorism and Political Identity in Indonesia: Fatally Belonging. Routledge, 2005.

Kartodirdjo, S., A. Sudewo, and S. Hatmosuprobo. Perkembangan Peradaban Priyayi. Gadjah Mada UP, 1987.

Kayam, Umar. Sri Sumarah dan Bawuk. Pustaka Jaya, 1975.

--. Sri Sumarah and Other Stories. Translated by Harry Aveling, Heinemann Educational Books, 1980.

--. Jalan Menikung (Para Priyayi 2). Grafiti, 1999.

--. Javanese Gentry. Translated by Vladislav Zhukov, The Lontar Foundation, 2013.

Kristanto, J. B. and W. Krastawan. "Harmoni Sumber Kemandulan." Kompas, 1986.

Nugroho, B. P. "Cerita Ahmad Tohari Soal Ronggeng Dukuh Paruk dan Tuduhan Sebagai PKI." Detik.com, 5 Dec. 2015, news.detik.com/berita/d-3088808/ cerita-ahmad-tohari-soal-ronggeng-dukuh-paruk-dan-tuduhan-sebagai-pki.

Rakindo, A. “Chinese Scapegoat Politics in Suharto's New Order." Ten Years' Military

Terror in Indonesia. Edited by Malcolm Caldwell, Spokesman Books, 1975, pp. 125-138.

Sidel, John T. Riots, Pogroms, Jihad. National U of Singapore P, 2007.

Spivak, Gayatri C. "Can the Subaltern Speak?" Marxism and the Interpretation of Culture. Edited by Cary Nelson and Lawrence Grossberg, U of Illinois P, 1988, pp. 271-313.

Sutherland, Heather. "The Priyayi." Indonesia, no. 19, 1975, pp. 57-77.

-.-Pangreh Pradja: Java's Indigenous Administrative Corps and Its Role in the Last Decades of Dutch Colonial Rule. Yale UP, 1973. 
Wessel, Ingrid. "The Politics of Violence in New Order Indonesia in the Last Decade of the 2oth Century." Violence in Indonesia. Edited by Ingrid Wessel and Georgia Wimhofer. Abera Verlag Markus Voss, 2001, pp. 64-81.

Winarta, F. H. "Racial Discrimination in the Indonesian Legal System: Ethnic Chinese and Nation-Building." Ethnic Relations and Nation-Building in Southeast Asia. Edited by Leo Suryadinata, ISEAS, 2004, pp. 66-81. 